\title{
Disabled person: construction of concept by this population
}

\author{
Pessoa com deficiência: construção do conceito por esta população
}

Persona con discapacidad: construcción del concepto por esta población

Lorita Marlena Freitag Pagliuca ${ }^{1}$, Paula Marciana Pinheiro de Oliveira ${ }^{2}$, Monaliza Ribeiro Mariano ${ }^{3}$, Jacqueline Mota da Silva ${ }^{1}$, Paulo Cesar de Almeida ${ }^{4}$, Giselly Oseni Barbosa Oliveira ${ }^{1}$

Objective: to build the concept of disabled person. Methods: study of analysis of concept using the phases field work and statistical analysis with 120 individuals divided into three groups of 40 people with hearing, visual and motor disability. Results: there was predomination of men (68.0\%), 18 -29 years old (55.0\%), with superior education $(35.0 \%)$ and married/ common-law married (75.0\%). The attribute accepted was person with limitation and still able to perform activity, with a difference between groups ( $\mathrm{p}=0.018)$; the keyword accepted was limitation $(\mathrm{p}=0.001)$; the expression was disabled person, with intergroup difference ( $\mathrm{p}=0.013)$. Concept of choice by group was deaf $(97.5 \%)$; blind $(45.0 \%)$ and person with visual disability (45.0\%) and; person with physical disability (27.5\%). Conclusion: attributes, keywords used in the literature and public policy were not accepted. They prefer to be called deaf; blind or visually impaired; They reject people with motor disability and wheelchair user.

Descriptors: Disabled Persons; Concept Formation; Mobility Limitation; Visually Impaired Persons; Persons with Hearing Impairments.

Objetivo: construir o conceito de pessoa com deficiência. Métodos: estudo de análise de conceito utilizando fases de campo e de análise estatística com 120 sujeitos divididos em três grupos de 40 pessoas com deficiência auditiva, visual e motora. Resultados: predominaram homens (68,0\%), de 18 a 29 anos (55,0\%), estudo superior (35,0\%) e casados/união estável (75,0\%). Atributo aceito foi pessoa com limitação e com capacidade de desempenhar atividade, com diferença entre grupos ( $\mathrm{p}=0,018)$; palavra-chave aceita, limitação $(\mathrm{p}=0,001)$; expressão pessoa com deficiência, com diferenças intergrupais ( $p=0,013)$. Conceito de escolha por grupo foi surdo $(97,5 \%)$; cego $(45,0 \%)$ e pessoa com deficiência visual $(45,0 \%)$ e; pessoa com deficiência física $(27,5 \%)$. Conclusão: atributos, palavras-chaves utilizadas na literatura e políticas públicas não foram aceitas. Preferem ser chamados de surdo; cego ou com deficiência visual; rejeitam pessoa com deficiência motora e cadeirante.

Descritores: Pessoas com Deficiência; Formação de Conceito; Limitação da Mobilidade; Pessoas com Deficiência Visual; Pessoas com Deficiência Auditiva.

Objetivo: construir el concepto de persona con discapacidad. Métodos: estudio de análisis de concepto utilizando las fases de campo y análisis estadístico con 120 sujetos divididos en tres grupos de 40 personas con discapacidad auditiva, visual y motora. Resultados: predominaron hombres (68,0\%), 18-29 años (55,0\%), estudio superior (35,0\%) y casados/en unión estable $(75,0 \%)$. Atributo acepto fue persona con limitación y capacidad para desarrollar actividad, con diferencia entre grupos ( $p=0,018)$; palabras clave aceptadas, limitación $(p=0,001)$; expresión persona con discapacidad, con diferencias intergrupales $(p=0,013)$. Concepto de elección por grupo fue sordo $(97,5 \%)$; ciego $(45,0 \%)$ y personas con discapacidad visual $(45,0 \%)$ y; persona con discapacidad física $(27,5 \%)$. Conclusión: atributos, palabras clave utilizadas en la literatura y políticas públicas no fueron aceptas. Prefieren ser llamados de sordo; ciego o con discapacidad visual; rechazan persona con discapacidad motora y en silla de ruedas.

Descriptores: Personas con Discapacidad; Formación de Concepto; Limitación de la Movilidad; Personas con Daño Visual; Personas con Deficiencia Auditiva.

\footnotetext{
${ }^{1}$ Universidade Federal do Ceará. Fortaleza, CE, Brazil.

${ }^{2}$ Universidade da Integração Internacional da Lusofonia Afro-Brasileira. Fortaleza, CE, Brazil.

${ }^{3}$ Centro Universitário Estácio do Ceará. Fortaleza, CE, Brazil.

${ }^{4}$ Universidade Estadual do Ceará. Fortaleza, CE, Brazil. 


\section{Introduction}

Understanding the social trajectory of the disabled person requires historical knowledge of exclusion, segregation, integration and inclusion. In exclusion, they were considered invalid and useless; in segregation, they were housed in large institutions, on a boarding school regime; in the integration period, there was intent to adapt the person to the environment; finally, the inclusion suggests that family and society must adapt to people's needs ${ }^{(1)}$.

Analysis of concept is a method that organizes the thought and communication; explains, clarifies key features of the concept of interest; unveils relevant factors, particular strategies, especially when there is more than one meaning; defines operating variables used by groups of researchers and proposes a sequence of steps that determine coherent and logical structure. It accepts the concept as dynamic, inaccurate and dependent on the context in which it is employed ${ }^{(2)}$. For this study, the adopted analysis of concept was the Hybrid Model that calls for field work with the target audience ${ }^{(3)}$.

The identification of backgrounds, attributes and consequences are phases common to most of the models of construction and analysis of concept. Backgrounds may consist of historical facts that have driven new ways of interpreting a given reality and are responsible for changes in language and interpretation of its meaning, including laws and social events. Attributes are essential characteristics that make up the concept, the explanatory or defining elements, explaining the fundamental characteristics of the object. Consequences make reference to how the attributes have influenced people, society and history.

In this context, a previous document analysis fulfilled the theoretical pole on the concept of disabled person, making use of documents that establish health care policies and literature on the theme that discussed related topics. This analysis of the historical evolution of the concept pointed as its backgrounds: the difficulty in gaining access to education, discrimination and denial of rights; as essential attributes: the loss, disability, limitation, restriction, deficit and impediment; and as its consequences: needs not covered, social exclusion, non-execution of laws, and need for a change in the attitudes of society ${ }^{(4)}$.

Although the models of analysis and construction of concept propose a step involving the target audience that receives or uses a given concept, studies with this approach are rare. Assuming that laws and scientific literature may not coincide with the perception and self-concept of the individuals, it is pertinent to submit these findings to appreciation by such individuals. In this perspective, the synthesis of results of the abovementioned document analysis ${ }^{(4)}$ shall be submitted to appreciation by people with hearing, visual and motor impairments.

A concept may have several meanings depending on the target audience. Thus, disabled people were heard and the following questions were formulated in order to guide this study: What backgrounds influenced the concept of person with disabilities in your opinion? Which attributes listed in official documents do you accept as characterizing you? Which denominations proposed along these lines, as a result, do you identify yourself with? Anyway, although showing respect for the fact that your denomination is your own name, how do you want to be named when it comes to your disability?

The aim of the study had support in the backgrounds, attributes and consequences of the analysis of concept, that is, the study was carried out after searching in literature what interfered in the theoretical concept of this clientele. The goal of the present research is to listen to people with disabilities and know how they want to be called.

\section{Method}

Hybrid model of the type Analysis of Concept consists of three phases: theoretical, field work and 
analytical. In the theoretical phase, the concept is researched in literature, compared and contrasted with existing definitions, in order to select and create a concept. In the field work, data is collected from a given population to deepen understanding of the selected concept; this way we are able to describe and explain the refinement according to empirical observation. The analytical approach makes use of statistics, allowing for refinement of the concept and its acceptability ${ }^{(3)}$. As mentioned, the theoretical phase was carried out in a previous study ${ }^{(4)}$ following the evolutionary model of analysis of concept.

The present study consists of an analysis of concept using the phases of field work and statistical analysis of the Hybrid Model ${ }^{(3)}$. The field phase consisted of data collection conducted in association of people with visual, hearing and motor disability (study population) in the period of March to August 2012. The sample, in turn, consisted of 120 individuals, 40 people with each one of the disabilities: hearing, visual and motor. Individuals were 18 years old or older, an established age that takes into account age of majority, responsibility and autonomy.

A questionnaire was applied with the following guiding questions: Which attributes identified in literature do you accept? Which keywords extracted from literature do you accept? Which concepts extracted from literature do you accept? And, how do you want to be called? The respective attributes, keywords and concepts of person with disabilities were listed and were answered in dichotomous scale of the type "yes" or "no". The last question, on how the person wants to be called, was open. Interview was held with people with visual impairments; in the case of deaf people, an interpreter responded using sign language; and those with motor disabilities responded without assistance.

Statistical associations between the type of disability and variable attributes identified in literature, keywords attribute and concepts taken from literature were tested using $\mathrm{c}^{2}$ and likelihood ratio. The choice of the concept of how they want to be called is presented in absolute and relative frequency. Significance level was fixed at $p<0.05$. Data was processed in Statistical Package for Social Sciences, version 20.0.

Principles of ethics with humans were respected. The study was approved by the Ethics Committee of the Federal University of Ceará with Opinion number 297/10.

\section{Results}

Among 120 individuals predominated men (68.0\%), aged between 18 and 29 years (55.0\%), with superior education (35.0\%), with income of $\mathrm{R} \$ 622.00$ - U\$179.58 (47.0\%) and married/commonlaw married $(75.0 \%)$.

Table 1 shows a comparison between the types of disabilities regarding the backgrounds in order to better conceptualize disabled people according to their own perception.

Table 1 - Distribution of the number of individuals by type of disability according to backgrounds identified in literature and acceptance thereof by persons with disabilities

\begin{tabular}{|c|c|c|c|c|}
\hline \multirow[b]{2}{*}{ Atributes } & \multicolumn{3}{|c|}{ Disability } & \multirow[b]{2}{*}{$\mathbf{p}^{(1)}$} \\
\hline & $\begin{array}{c}\text { Hearing } \\
\text { n(\%) }\end{array}$ & $\begin{array}{l}\text { Visual } \\
\text { n(\%) }\end{array}$ & $\begin{array}{l}\text { Motor } \\
\text { n(\%) }\end{array}$ & \\
\hline Inability to secure needs & & & & $0.298^{(1)}$ \\
\hline Yes & $9(22.5)$ & $4(10.0)$ & $8(20.0)$ & \\
\hline No & $31(77.5)$ & $36(90.0)$ & $32(80.0)$ & \\
\hline $\begin{array}{l}\text { Loss or abnormality of } \\
\text { structure or function }\end{array}$ & & & & $0,004^{(1)}$ \\
\hline Yes & $4(10.0)$ & $17(42.5)$ & $10(25.0)$ & \\
\hline No & $36(90.0)$ & $23(57.5)$ & $30(75.0)$ & \\
\hline $\begin{array}{l}\text { Limitation/loss of a part } \\
\text { of the body }\end{array}$ & & & & $<0.0001^{(1)}$ \\
\hline Yes & $4(10.0)$ & $20(50.0)$ & $20(50.0)$ & \\
\hline No & $36(90.0)$ & $20(50.0)$ & $20(50.0)$ & \\
\hline $\begin{array}{l}\text { Limitation/dependent } \\
\text { for activities of daily life }\end{array}$ & & & & $0.834^{(1)}$ \\
\hline Yes & $9(22.5)$ & $11(27.5)$ & $9(22.5)$ & \\
\hline No & $31(77.5)$ & $29(72.5)$ & $31(77.5)$ & \\
\hline $\begin{array}{l}\text { Physical, mental or sen- } \\
\text { sory impairment }\end{array}$ & & & & $0.016^{(1)}$ \\
\hline Yes & $6(15.0)$ & $16(40.0)$ & $7(17.5)$ & \\
\hline No & $34(85.0)$ & $24(60.0)$ & $33(82.5)$ & \\
\hline $\begin{array}{l}\text { Limitations, but able to } \\
\text { perform activities }\end{array}$ & & & & $0.018^{(1)}$ \\
\hline Yes & $21(52.5)$ & $32(80.0)$ & $30(75.0)$ & \\
\hline No & $19(47.5)$ & $8(20.0)$ & $10(25.0)$ & \\
\hline
\end{tabular}


Rejected backgrounds were considered differently among the three types of disabilities: loss or abnormality of structure or function $(p=0.004)$; limitation/loss of a part of the body $(\mathrm{p}<0.0001)$, physical or sensory impairment $(\mathrm{p}=0.016)$. People with limitations but still able to perform activities $(p=0.018)$ was the only feature accepted by most individuals.

Table 2 exposes attributes that characterize people with disabilities to clientele itself.

Table 2 - Distribution of the number of individuals by type of disability according to attributes identified in literature that influence their acceptability

\begin{tabular}{|c|c|c|c|c|}
\hline \multirow[b]{2}{*}{ Meanings } & \multicolumn{3}{|c|}{ Disability } & \multirow[b]{2}{*}{$\mathbf{p}^{(1)}$} \\
\hline & $\begin{array}{c}\text { Hearing } \\
\text { n(\%) }\end{array}$ & $\begin{array}{c}\text { Visual } \\
\text { n(\%) }\end{array}$ & $\begin{array}{c}\text { Motor } \\
\text { n(\%) }\end{array}$ & \\
\hline Loss & & & & $0.049^{(1)}$ \\
\hline Yes & $8(20.0)$ & $14(35.5)$ & $5(12.5)$ & \\
\hline No & $32(80.0)$ & $26(65.0)$ & $35(87.5)$ & \\
\hline Inability & & & & $0.132^{(2)}$ \\
\hline Yes & $8(20.0)$ & $3(7.5)$ & $3(7.5)$ & \\
\hline No & $32(80.0)$ & $37(92.5)$ & $37(92.5)$ & \\
\hline Limitation & & & & $0.001^{(1)}$ \\
\hline Yes & $16(40.0)$ & $32(80.0)$ & $25(62.5)$ & \\
\hline No & $24(60.0)$ & $8(20.0)$ & $15(37.5)$ & \\
\hline Restriction & & & & $0.137^{(1)}$ \\
\hline Yes & $8(20.0)$ & $11(27.5)$ & $4(10.0)$ & \\
\hline No & $32(80.0)$ & $29(72.5)$ & $36(90.0)$ & \\
\hline Deficit & & & & $<0.0001^{(1)}$ \\
\hline Yes & $16(40.0)$ & $7(17.5)$ & $2(5.0)$ & \\
\hline No & $24(60.0)$ & $33(82.5)$ & $38(95.0)$ & \\
\hline Impediment & & & & $0.128^{(2)}$ \\
\hline Yes & $5(12.5)$ & $8(20.0)$ & $2(5.0)$ & \\
\hline No & $35(87.5)$ & $32(80.0)$ & $38(95.0)$ & \\
\hline Exclusion & & & & $0.094^{(1)}$ \\
\hline Yes & $13(32.5)$ & $11(27.5)$ & $5(12.5)$ & \\
\hline No & $27(67.5)$ & $29(72.5)$ & $35(87.5)$ & \\
\hline
\end{tabular}

Attributes identified in literature were strongly rejected by studied individuals. Outstanding among these, with significant difference between the three types of disabilities, were: loss ( $\mathrm{p}=0.049)$; limitation $(\mathrm{p}=0.001)$ (this attribute was not rejected by visually or motor-impaired persons); and deficit $(\mathrm{p}<0.0001)$.
Table 3 shows the consequent phrases that build the self-concept of Persons with disabilities.

Table 3 - Distribution of the number of individuals by type of disability and consequences to the elaboration of the concept

\begin{tabular}{lcccc}
\hline \multirow{2}{*}{ Denominations } & \multicolumn{4}{c}{ Disability } \\
\cline { 2 - 5 } & $\begin{array}{c}\text { Hearing } \\
\mathbf{n ( \% )}\end{array}$ & $\begin{array}{c}\text { Visual } \\
\mathbf{n ( \% )}\end{array}$ & $\begin{array}{c}\text { Motor } \\
\mathbf{n ( \% )}\end{array}$ & $\mathbf{p}^{(1)}$ \\
\hline Person bearing* disability & & \multicolumn{3}{c}{0.009} \\
$\quad$ Yes & - & $2(5.0)$ & $7(17.5)$ \\
No & $40(100.0)$ & $38(95.0)$ & $33(82.5)$
\end{tabular}

Person bearing* special needs 0.025 Yes

No

$\begin{array}{ccc}- & 1(2.5) & 5(12.5) \\ 40(100.0) & 39(97.5) & 35(87.5)\end{array}$

Person with special rights

Yes

No

Person with special needs

Yes

No

0.164

$\begin{array}{lll}- & 1(2.5) \quad 3(7.5)\end{array}$

$40(100.0) 39(97.5) \quad 37(92.5)$

0.047

$\begin{array}{lll}- & 4(10.0) \quad 6(15.0)\end{array}$

$40(100.0) 36(90.0) 34(85.0)$

Person with special educa-

tional needs

0.164

Yes

$\begin{array}{ccc}- & 1(2.5) & 3(7.5) \\ 0(100.0) & 39(97.5) & 37(92.5)\end{array}$

No

$\begin{array}{ccc}- & 1(2.5) & 3(7.5) \\ 40(100.0) & 39(97.5) & 37(92.5)\end{array}$

Special person

Yes

No

Disabled person

Yes

No

Exceptional person

Yes

No

$\begin{array}{lll}- & 2(5.0) \quad 2(5.0)\end{array}$

40(100.0) 38(95.0) 38(95.0)

0.355

$3(7.5) \quad 1(2.5) \quad 5(12.5)$

$37(92.5) \quad 39(97.5) \quad 35(87.5)$

0.365

Person with disability

Yes

$2(5.0) \quad 7(17.5) \quad 12(30.0)$

$\begin{array}{lllll}\text { No } & 38(95.0) & 33(82.5) & 28(70.0)\end{array}$

$\mathrm{p}^{(1)}$ Likelihood ratio test; ${ }^{*}$ Typical term of Brazilian Portuguese vocabulary in this context

Consequences identified in literature and legislation on health of people with disabilities that were not accepted by the three groups. There was no statistically significant difference between groups in the expressions: Person bearing disability $(\mathrm{p}=0.009)$, Person bearing special needs $(\mathrm{p}=0.025)$, Person with special needs $(\mathrm{p}=0.047)$ and person with disability $(\mathrm{p}=0.013)$. 
Table 4 shows the distribution of individuals according to type of disability, showing their choice on how they accept to be named.

Table 4 - Distribution of individuals according to type of disability and choice on how they accept being named

\begin{tabular}{lcc}
\hline \multirow{2}{*}{ Denomination } & Yes & No \\
\cline { 2 - 3 } & $\mathbf{n}(\%)$ & $\mathbf{n}(\%)$ \\
\hline Hearing $(\mathrm{n}=40)$ & & \\
$\quad$ Person with hearing disability & $2(5.0)$ & $38(95.0)$ \\
$\quad$ Deaf & $39(97.5)$ & $1(2.5)$ \\
Visual (n=40) & & \\
$\quad$ Person with visual disability & $18(45.0)$ & $22(55.0)$ \\
$\quad$ Blind & $18(45.0)$ & $22(55.0)$ \\
Motor (n=40) & & \\
$\quad$ Person with motor disability & $11(27.5)$ & $29(72.5)$ \\
$\quad$ Wheelchair user & $2(5.0)$ & $38(95.0)$ \\
\hline
\end{tabular}

Hearing impaired people accept to be named deaf (97.5\%); visually impaired people accept to be named Person with visual disability $(45.0 \%)$ and blind (45.0\%). Those with motor disability denied the expression person with motor disability (72.5\%) and wheelchair user (95.0\%).

\section{Discussion}

The analysis of concept supported by literature regarding historical events and legislation that relate to persons with disabilities identified backgrounds, attributes and consequences that characterize this population ${ }^{(4)}$. Backgrounds, presented in sentences, were quantified; attributes were synthesized in keywords and the consequences, in sentences with approximation of what is concept. By submitting these words or expressions to screening by this population we seek to validate them for widespread use.

Evaluation of the acceptability of backgrounds showed that there are significant differences between the groups surveyed. Thus, loss or abnormality of structure or function was rejected by people with hearing and motor impairments and to a lesser extent, by people with visual impairment. The term disability points to a negative interaction between the individual and contextual, environmental and social factors $^{(5)}$. Issues related to gender also interfere in the construction of concept. Men and women have distinct identities and understand differently feelings such as operation and control, action and emotion ${ }^{(6)}$. In this study, gender was not a variable considered, but we point out to the relevance of its adoption in future studies, as well as age, education level and labor activity.

The three groups of study said they have limitations but are still able to perform activity. They refuse backgrounds listed in legislation and health literature that describe them with loss or abnormality of structure or function, with limitation or loss of part of the body, with limitations or dependence in the daily life, and with physical or sensory limitations. These expressions are recurrent in the documents on public policies for health ${ }^{(7)}$.

Words such as disability, loss, restriction, deficit, impairment and exclusion, present in the statements of the attributes listed in literature and law, are represented in a negative way for the people of this study, which led to the rejection of the same. Only the word limitation is positively recognized and it was the expression accepted by the three groups, despite differences between them. We must take into account that the sample consists mostly of young adults, a third with higher education although with income only slightly higher to the minimum wage ( $\mathrm{R} \$ 622.00$ - U\$179.58). These are people who attend regular or special school, recreational and cultural associations. This social context makes them perceive the world and themselves as participatory people with social integration and persons who define their future.

Thus, the essential background selected by the majority of individuals were people with limitations but able to perform activities. This result shows that they perceived themselves positively, as capable of performing functions, so that their disability does not prevent them to perform tasks. These results coincide 
with a study pointing to the need of considering the influence of social, economic, work-related factors for the construction of one's self concept of the person with disabilities. It has been recorded that when these conditions are favorable, social inclusion occurs ${ }^{(8)}$.

While exploring the daily lives of children and youth with inabilities related to the practice of physical activities in internal and external environments to school, it has been found that most can perform daily activities without difficulty. This shows that people with disabilities are becoming autonomous and independent. This can be probably related to the change in the way of life encouraged by the inclusion in $\operatorname{schools}^{(9)}$. A disabled person claimed to feel able to do the same activities that a person without a disability does and that this means quality of life ${ }^{(10)}$.

Loss or abnormality of structure or function was rejected by people with hearing disabilities. This finding is corroborated by a study that shows the physical experience of loss of hearing as secondary in the representation of deafness. Therefore, deafness is not defined by the absence of the sense of hearing or as disability, but rather it is anchored in cultural and linguistic components in which a person is considered deaf because he/she shares common experiences in his/her community universe through perception and visual communication by sign language and not because he/she have hearing loss ${ }^{(11)}$.

By analyzing people's perceptions about their disabilities, it is clear that this clientele, in particular persons with hearing limitations, do not see themselves as individuals missing a member, or with restrictions. Indeed, disability is different from that; it is a phenomenon defined by the degree of difficulty to relate to and integrate into the social environment, which will define those who have disabilities or not. Thus, the problem lies not in the individual but in their relationship with society ${ }^{(12)}$.

On the other hand, with the acknowledgement of diversity and inclusion, disability is no longer viewed as a purely physical or sensory problem of the individual, once it is not only that person that has a disability: the entire society has a disability, once it does not meet the pertinent needs of differences or guarantee the citizenship of its members ${ }^{(13)}$.

The practice of social inclusion, which is replacing social integration, is based on universal design and for that, everyone must be transformed with the intent to meet the needs of its members. Hence, inclusion does not allow prejudice, discrimination, social, cultural and personal barriers. Social inclusion of people with disabilities means respecting their demands and avoiding attitudinal barriers in any environment or area ${ }^{(14)}$.

The attribute loss, although accepted by a small percentage of the three disabilities, had greater acceptance among visually disabled and the lower among motor-disabled. It is suggested that this loss was not associated with loss of one part of the body. This attribute was possibly understood as limitation by the group of visually and motordisabled; they accept limitation as an attribute that influences their self-concept. Disability is defined as reduction, limitation or absence of perception of conditions of environmental characteristics, or mobility and use of space, furniture, equipment and urban elements, including the limitation as a feature of this clientele ${ }^{(15)}$. In the other hand, some people with hearing loss did not consider that limitation is an attribute that characterizes them, while the literature states that hearing disability implies limitations in the performance of activities in the social environment, including at work, where the individual is prevented from showing his/her potential, since the spoken language is more appreciated in that environment ${ }^{(16)}$.

There were significant differences between the groups regarding the acceptance of the consequences extracted from literature. People with hearing disabilities rejected expressions such as person bearing disability, person with special needs and person bearing special needs. These expressions received small percentage of acceptance by people with visual and motor disabilities. These expressions were introduced in legislation as a way to mitigate or soften 
the denomination of this group, but the investigated groups argue that disability is not something that the person bears, something the person carries with him/ her as an object that can be put aside whenever he/ she wants. In fact, disability is something that you do not bear, but you have. Disability is part of the person. These are the speeches of the visually impaired, deaf and people with physical disabilities.

As regards the nomenclature, 'person bearing disability' was replaced by 'person with disability', henceforth officially used when referring to this clientele ${ }^{(14)}$. However, when analyzing the acceptance of that name in our sample, it seems that this was accepted only by a low percentage of individuals. As for the expression 'person with special needs', this is not accepted as specific to the group, since it refers to the elderly, pregnant women, chronically ill, dependent on technical support, and so forth, basically implying any situation involving differential treatment. Its origin is rooted in the area of education, while discoursing about people with special needs for learning, including the blind, deaf, those with learning disabilities, gifted, autists ${ }^{(7)}$.

In the case of consolidation of keywords of attributes, a way to understand how much the word is accepted or rejected, shows that loss, disability, restriction, deficit, impairment and exclusion were rejected by the three groups despite differences between them. Limitation was accepted by people with visual and motor disabilities. A study on health legislation of four English-speaking countries in Africa shows that vulnerable groups such as ethnic minorities, mother/child and disabled persons are often not mentioned. The use of expressions like for everyone or for all people hide the true health needs of minority groups. Authors propose a comprehensive concept for the disability where interaction with this individual and interaction between him and the environment are valued ${ }^{(17)}$.

In addition to the study of words and descriptions that represent certain population group, symbolic figures are also used. These have the advantage of universal understanding for they are independent of spoken or written language. In this way, the visually impaired person is represented standing and with an outstretched crutch; an ear symbolizes the person with hearing impairment; wheelchair symbolizes the motor-disabled person. This non-verbal language signals the accessibility to environments, marks preference spaces in parking lots and priority attendance. In this study, the options "person with motor disability" and "wheelchair user" were presented, but only two individuals identified themselves with the written expression of the international symbol, because they are not wheelchair users or because, certainly, it does not represent them. It is important to emphasize the need for broadened and deepened reflection on the theme of the study.

Evolving for the synthetic expression of how these people accept to be named, those with hearing impairment prefer "deaf"; those with visual impairment prefer "person with visual disability" or "blind". People with motor limitation refused the denomination "Person with motor disability" and "wheelchair user", requiring new investigations.

Reflections on the concept of the person with disabilities illuminate the individual and the society. In the beam of light, what is visible, evident, is more easily identified and respected. Invisible attributes or characteristics of limitations go unnoticed, hindering social inclusion. Attentive and solidarity posture allows us to see when the other fellow is under an unprotected condition and in need of solidarity.

\section{Conclusion}

In view of the findings, two groups of individuals, respecting their specificities, accept being called deaf (97.5\%); visually impaired (45.0\%) and/ or blind $(45.0 \%)$. The subset of people with motor limitation does not accept the denomination "person with motor disability" (72.5\%) or "wheelchair 
user" (95.0\%). Therefore, further studies should be conducted in search of an acceptable name. Among the essential backgrounds featuring the three groups, there is acceptance of the term "limited but able to perform activity". Confirming the characterization accepted, the attribute "limitation" was the most accepted among hearing (40.0\%), visual (80.0\%) and motor $(62.5 \%)$ impaired.

The rejection of the words inability, loss, restriction, deficit, impairment and exclusion was evident, all expressions present in the related statements in literature and law. Only the attribute limitation is recognized and accepted positively by this clientele. Also, the definition of disability developed by national bodies was not accepted by this population, showing that they are not abnormal and that they present a limitation that does not prevent them from undertaking any activities that may be proper to them.

It is important to clarify that some visually impaired people were blind and others had poor vision, which may have helped in this division. In addition, people with motor disabilities are not necessarily wheelchair users, causing this study to have the limitation that there were few people who wanted to be denominated so.

Future research with statistically significant number and different regions of the country should be carried out in order to make possible to generalize results, what would be essential to raise proper and acceptable denominations for this population. Also, socioeconomic variables that possibly influence the concept of construction must be included in the analysis.

\section{Acknowledgements}

We thank the Fundação Cearense de Apoio ao Desenvolvimento Científico e Tecnológico and Conselho Nacional de Desenvolvimento Científico e Tecnológico, for granting scholarship.

\section{Collaborations}

Pagliuca LMF contributed to conception and design, article writing, relevant critical review of the intellectual content and final approval of the version to be published. Oliveira PMP, Mariano MR and Silva JM contributed to the writing of the article, collection and relevant critical review of the intellectual content. Almeida PC contributed to the analysis and interpretation of data. Oliveira GOB contributed to writing of the article and final approval of the version to be published.

\section{References}

1. Braga MMS, Schumacher AA. Direito e inclusão da pessoa com deficiência: uma análise orientada pela teoria do reconhecimento social de Axel Honneth. Soc Estado. 2013; 28(2):375-92.

2. Avant KC. The Wilson method of concept analysis. In: Rodgers BL, Knafl KA. Concept development in nursing: foundations, techniques and applications. Philadelphia: Saunders; 2000. p.55-64.

3. Schwartz-Barcott D, Kim HS. An expansion and elaboration of the hybrid model of concept development. In: Rodgers BL, Knafl KA. Concept development in nursing: foundations, techniques and applications. 2 ed. Philadelphia: Saunders; 2000. p.129-60.

4. Baptista RS, Pagliuca LMF. Pessoa com deficiência numa perspectiva evolucionária: análise de conceito. Online Braz J Nurs. [Internet] 2009 [citado $2014 \mathrm{dez}$ 13]; 8(3). Disponível em: http:// www.objnursing.uff.br/index.php/nursing/ article/view/j.1676-4285.2009.2511/551

5. Di Nubila H, Paula AR, Marcelino MA, Maior I. Evaluating the model of classification and valuation of disabilities used in Brazil and defining the elaboration and adoption of a unique model for all the country": Brazilian Interministerial Workgroup Task. BMC Public Health [Internet] 2011 [cited 2014 Dec 13]; 11(Suppl 4):10. Available from: http://www.biomedcentral.com/ content/pdf/1471-2458-11-S4-S10.pdf 
6. Foster D, Wass V. Disability in the labour market: an exploration of concepts of the ideal worker and organisational fit that disadvantage employees with impairments. Sociology. 2014; 47(4)705-21.

7. Carvalho LV, Áfio ACE, Rodrigues Junior, JC, Rebouças CBA, Pagliuca LMF. Advances in health promotion for people with disabilities and the laws of Brazil. Health. 2014; 6(18):2365-74.

8. Foster D, Fosh P. Negotiating 'difference': Representing disabled employees in the British workplace. $\mathrm{Br} \mathrm{J}$ Industrial Relations 2010; 48(3):560-82.

9. Jung LG, Marques AC, Kalinoski AX, Xavier GB. Cotidiano da prática de atividade física de crianças e jovens com deficiências da Rede Municipal de Pelotas-RS. Movimento. 2013; 19(2):207-26.

10. Wadensten B, Ahlström G. Ethical values in personal assistance: narratives of people with disabilities. Nurs Ethics. 2009; 16(6):759-74.

11. Nóbrega JD, Andrade AB, Pontes RJS, Bosi MLM, Machado MMT. Identidade surda e intervenções em saúde na perspectiva de uma comunidade usuária de língua de sinais. Ciênc Saúde Coletiva. 2012; 17(3):671-9.

12. Leite FP. A Convenção sobre os direitos das pessoas com deficiência: amplitude conceitual. Rev Direito Bras. 2012; 3(2):31-53.
13. Maia LM, Camino C, Camino L. Pessoas com deficiência no mercado de trabalho: uma análise do preconceito a partir das concepções de profissionais de recursos humanos. Pesq Prát Psicossoc. 2011; 6(1):78-91.

14. Brasil. Presidência da República. Secretaria de Direitos Humanos. Portaria no 2.344 , de 3 de novembro de 2010. [Internet]. 2010 [citado 2014 dez 13]. Disponível em: http://www.udop. com.br/download/legislacao/trabalhista/pcd/ port_2344_pcd.pdf

15. Associação Brasileira de Normas Técnicas. NBR 9050, 2004. Acessibilidade a edificações, mobiliário, espaços e equipamentos urbanos. [Internet]. 2004 [citado $2014 \mathrm{dez}$ 13]. Disponível em:www.pessoacomdeficiencia.gov.br/app/ sites/default/files/arquivos/\%5Bfield_generico_ imagens-filefield-description\%5D_24.pdf

16. Francelin MAS, Motti TFG, Morita I. As implicações sociais da deficiência auditiva adquirida em adultos. Saúde Soc. 2010; 19(1):180-92.

17. Mannan H, McVeigh J, Amin M, MacLachlan M, Swartz L, Munthali A, Rooy GV. Core concepts of human rights and inclusion of vulnerable groups in the disability and rehabilitation policies of Malawi, Namibia, Sudan, and South Africa. J Dis Policy Studies. [Internet] 2012 [cited $2014 \mathrm{dez} 13$ ]. Available from: http://dps.sagepub.com/content/ early/2012/05/15/1044207312439103.full. pdf+html 